\author{
Aleksandra Stamenković DOI: https://doi.org/10.18485/slovenika.2018.4.1.4 \\ Izdavačka kuća „Klett“ \\ Beograd, Srbija \\ UDK: 72.071 .1 Plečnik J. \\ 726(497.11) \\ a_stamenkovic@ymail.com \\ Pregledni članak
}

\title{
Doprinos Jožeta Plečnika arhitekturi Beograda
}

\section{Sažetak}

Jože Plečnik pripada generaciji istaknutijih slovenačkih i jugoslovenskih arhitekata čija su dela ostavila značajan pečat u Beču, Pragu i Ljubljani, ali i u Beogradu. Umetnički put gradio je na temeljima klasičnih izvora arhitekture, $\mathrm{u}$ vremenu deklarisanja modernog pokreta $\mathrm{u}$ umetnosti. Iz spoja istorijskih i savremenijih umetničkih tokova nastao je specifični umetnički izraz Jožeta Plečnika. Odstupanje od aktuelnih tokova i čistih, a praznih površina bilo je pokušaj osavremenjivanja graditeljske baštine primesama jedinstvenog umetničkog duha. Njegova dekorativna arhitektura je mnogo bogatija i kompleksnija od utiska koji na prvi pogled stvara, i ona komunicira kako sa onima koji je neposredno koriste, tako i sa onima koji je u naučno-istraživačkom postupku posmatraju. Cilj ovog priloga proučavanju Plečnikovog rada jeste pokušaj osvetljavanja njegovog doprinosa javnom prostoru Beograda, izražen reprezentativnim hramom Sv. Antuna Padovanskog u Bregalničkoj ulici (opština Vračar).

Ključne reči: Jože Plečnik, Beograd, crkva Sv. Antuna, rimokatolička crkva u Obrenovcu, sakralna arhitektura, kapela Usmiljenki, DSNO

U jugoslovenskoj arhitekturi modernog doba, doslednost specifičnoj ideologiji i romantičarski inspirisanim oblicima izdvojila je delo Josipa (Jožeta) Plečnika (Ljubljana 23. 1. 1872-Ljubljana 7. 1. 1957). Opus proslavljenog slovenačkog (i jugoslovenskog) arhitekte dobro je poznat domaćoj stručnoj javnosti. Za to je zaslužan niz 
studija $^{1}$ i izložbi $^{2}$ posvećenih ovom stvaraocu. Imajući to na umu, prilog proučavanju njegove arhitekture u prestonici tadašnje jugoslovenske države može se posmatrati kao doprinos tumačenju njegove ličnosti i dela.

\section{Stvaralački put arhitekte Plečnika}

Jože Plečnik je bio istaknuti arhitekta, nacionalni radnik i jedna od uglednijih ličnosti (jugo)slovenske kulturne scene. Put u arhitekturu vodio ga je preko Graca i Beča (Mušič 1970, 251). Nakon završene Državne zanatske škole u Gracu 1894. godine, on se seli u Beč. Studirao je arhitekturu na Akademiji likovnih umetnosti u Beču, od 1895. do1898. godine, kod Ota Vagnera, a nekoliko je godina proveo i u njegovom ateljeu (Kocjan 2017, 1). Vodeći austrijski arhitekta toga doba imao je veoma zapaženu ulogu u obrazovanju mladog Plečnika. ${ }^{3}$ Nakon povratka sa studijskog putovanja u Italiju i Francusku, ${ }^{4}$

\footnotetext{
${ }^{1}$ Naučni doprinos istraživanju arhitekture Jožeta Plečnika dali su mnogi tumači moderne jugoslovenske arhitekture. Među njima se ističu: Deroko, Aleksandar. 1932. „Prvi monumentalni hram u Beogradu“. Srpski književni glasnik, Beograd: 630-631; Hrausky, Andrej, Koželj Janez i Damjan Prelovšek. 1998. „Plečnik v tujini“. Vodnik po arhitekturi, Ljubljana: 220-231; Krečič, Peter. 1990. „Jože Plečnik and Art Deco“, The Journal of Decorative and Propaganda Arts, Vol. 17: 26-35; Krečič, Peter. 1997. Jože Plečnik-Branje oblik. Ljubljana: DZS; Krećič, Peter. 1999. Jože Plečnik - moderni klasik. Ljubljana: DZS; Krećič, Peter. 2000. „Jože Plečnik in prenova cerkvene umetnosti na Slovenskom“. Poligrafi 19/20, Ljubljana, 7-20; Manević, Zoran. 1983. „Plečnik u Beogradu“. Sveske 14-15: 132-134; Mušič, Marjan. 1970. „Plečnik i Beograd“.ZZbornik Matice srpske za likovne umetnosti 6, Novi Sad: 249-265; Prelovšek, Damjan. 2000. „Arhitekta Plecnik in sakralna umetnost“. Poligrafi 19/20, Ljubljana : 135-145; Prosen, Milan. 2014. Ar deko u srpskoj arhitekturi, doktorska disertacija, Beograd: Filozofski fakultet: 16, 56, 502-504 itd.
}

${ }^{2}$ Među zapaženijima su izložbe iz 1983. godine na Akademiji Oksford, 1986. godine u Parizu, u Centru Pompidu, 1996. godine u praškoj tvrđavi („Josip Plecnik: Architecture of the New Democracy“), 2017. godine u Beogradu, povodom šezdesetogodišnjice Plečnikove smrti, u Ustanovi kulture „Parobrod“itd.

${ }^{3}$ Po dolasku u Beč, Plečnik se bavio dizajniranjem nameštaja, ali je istovremeno mnogo vremena provodio u galerijama, muzejima i na izložbama. Na jednoj od izložbi video je Vagnerov nacrt za Berlinsku katedralu, nakon čega je počeo pokazivati veliko interesovanje za arhitekturu. Dominacija Vagnerovog izraza mogla se prepoznati i u projektima koje je crtao tokom studija, a koje karakterišu racionalna organizacija prostora i planiranje. Videti: Ivan Lovrenović, Jozo Džambo, Architectura perennis, http://ivanlovrenovic.com/2012/07/jozo-dzambo-architectura-perennis/ (pristupljeno novembra 2018).

\footnotetext{
${ }^{4}$ Kao nagradu za diplomski rad, projekat uređenja kupališta Ševeningen kod Haga, Jože Plečnik je dobio Nagradu Rima i stipendiju koja mu je omogućila višemesečno studijsko putovanje po Italiji i Francuskoj. Videti: Kocjan, Ana. 2017. Jože Plečnik, Ljubljana - Prag - Beograd. Beograd: Nacionalni savet slovenačke nacionalne manjine: 1.
} 


\section{A. Stamenković \\ Doprinos Jožeta Plečnika arhitekturi...}

godine 1901. Plečnik osniva svoj arhitektonski studio u Beču. Deset godina kasnije biva imenovan za profesora dekorativne arhitekture na Umetničko-zanatskoj akademiji u Pragu i ostaje na tom položaju do 1920. godine, kada prelazi u Tehničku visoku školu u Ljubljani, u kojoj je kao profesor radio do 1935 . godine. ${ }^{5}$

Interesantan obrazovni put arhitekte Plečnika je za posledicu imao složeni kulturni identitet, koji uporedo favorizuje građanske ideale evropske elite i nacionalni patriotizam. Prateći njegovo umetničko stasavanje, preko ranih projekata koje karakterišu racionalizacija prostora i planiranje kakvo se moglo videti u Vagnerovim nacrtima, pa do objekata koje je gradio s klasicističkim, renesansnim i baroknim referencama, način na koji je uzdigao kontekst uobičajenih aktivnosti rezultirao je stvaranjem specifičnog graditeljskog rečnika (Petrić and Graham 2008, 105). Na definisanje Plečnikovog izraza, osim Vagnera, uticalo je „umetničko hodočašće“ u Italiju i Francusku 1899. godine, kao i kasnija putovanja sa studentima iz Ljubljane u Dalmaciju i Grčku (Petrić and Graham 2008, 106).

Delatnost Jožeta Plečnika se, osim projektantske i profesorske prakse, sastojala od rada na nadgrobnim spomenicima, liturgijskim predmetima i knjigama (Kocjan 2017, 1). Njegovo ime vezuje se za neke od najlepših građevina Beča ${ }^{6}$, Praga ${ }^{7}$ i Ljubljane ${ }^{8}$ (Krečič 1990, 28). Tokom svoje duge karijere, Plečnik je boravio i u Beogradu (Vasović-Mekina 2007). Svestranost u umetnosti mu je od prvih stvaralačkih dana donela uticajne mecene, među kojima se u literaturi pominju članovi kraljevske porodice Karađorđević, kao i predstavnici

\footnotetext{
${ }^{5}$ Afirmacija lika i dela Jožeta Plečnika opisana je u svim bibliografskim jedinicama pomenutim u fusnoti 1 .

${ }^{6}$ Bečki period Plečnikovog života obeležen je veoma reprezentativnom crkvom Sv. Duha na Otakringu (1910). Na njoj primenjuje armirano-betonski nosač za premošćenje galerija, što ranije nije bilo uobičajeno za sakralnu arhitekturu. Među objektima privatne namene naročito se ističe palata Caherl (1903-1905), jer se simbolično vezuje za Plečnikovo oslobađanje uticaja Ota Vagnera.

${ }^{7}$ Praški period obeležio je rad na dvorskom kompleksu Hradčani (1920-1938), sedištu predsednika Čehoslovačke Republike, što se ujedno ubraja i u najvažnija dostignuća evropske vrtne arhitekture u međuratnom periodu. Od sakralnih objekata, ovaj period u Plečnikovoj projektantskoj biografiji obeležila je i crkva Presvetog srca Isusovog na Karlovim Vinogradima (1931).

${ }^{8}$ Plečnikova ljubav i angažovanje na uređenju rodnog grada uslovili su sadašnji izgled slovenačke prestonice. Osim što je odgovoran za projekat urbanističke obnove Ljubljane, izgradio je i obnovio veliki broj građevina, privatnih kuća i poslovnih zgrada. Među njima se izdvajaju: crkva Sv. Franje Asiškog (1925-1930), crkva Sv. Mihovila na Barju (1937-1939), Orlovski stadion (1925-1935), Tromostovlje i Čevljarski most (1929-1932), Narodna i univerzitetska biblioteka (1936-1941), Tržnice (1941-1945), i drugi objekti.
} 
vlade socijalističke Jugoslavije (Strajnić 1925, 461; Quek et al 2012, 101; Jovanović 2016a, 57).

Nezavisno od toga da li prethode potrebama ili na njih odgovaraju, arhitektonske forme neposredno reflektuju shvatanje arhitekture i položaj arhitektonskog stvaralaštva u određenom društvu. Budući da je umetnost uvek diskurzivna, umetnik - svesno ili ne - svojim delovanjem zauzima stav prema okolnostima u kojima deluje, te aktivno ispunjava ideološku funkciju (Dinulović i Bošković 2010, 50). Izučavanjem dostupne građe mogu se uočiti ideološki i kulturni obrisi intelektualnog i profesionalnog statusa Jožeta Plečnika i $\mathrm{u}$ periodu aktivnog stvaranja i nakon određene istorijske distance. On je vodio računa o kulturno-istorijskom identitetu prostora na kome je stvarao, pa je njegov opus obeležila sinteza lokalnog graditeljstva sa klasičnim izvorima i elementima secesijske i moderne arhitekture. Povezivao je arhitekturu sa primenjenom umetnošću, te je na oblicima istovremeno isticao dekorativnost i monumentalnost (Kocjan 2017, 1). Odstupanje od glavnih umetničkih tokova je u slučaju Plečnikovih objekata bilo uobičajeno i ne treba ga tumačiti kao zaostajanje, već ga treba posmatrati kao pokušaj predstavljanja novog stilskog poretka (Vasović-Mekina 2007). Njegovu specifičnost dodatno je istaklo pojačano interesovanje za sakralnu arhitekturu i aktivno učestvovanje kako u projektovanju novih crkava tako i u rekonstrukcijama starih (Sikošek 2017).

Plečnikov rad je dobio priznanje u lokalnim i međunarodnim okvirima. On je bio nosilac ordena reda Svetog Save i reda Zasluga za narod. Godine 1932. izabran je za počasnog člana Češke akademije nauka i umetnosti, dok je 1938. izabran za člana SAZU (Slovenske akademije znanosti in umetnosti. Pored počasnih doktorata Arhitektonskog fakulteta u Ljubljani i Tehničke visoke škole u Beču, godina 1952. donela mu je i članstvo u Masarikovoj akademiji u Pragu. Bio je i korespodent Britanskog kraljevskog instituta (RIBA) od 1954. godine (Kocjan 2017, 1).

\section{Veze sa Beogradom}

Arhitekta Jože Plečnik je prvi put u Beograd svratio vraćajući se sa studentima sa ekskurzije u Grčkoj, 1925. godine. Međutim, nije se dugo zadržao u prestonici tadašnje Kraljevine Srba, Hrvata i Slovenaca, već je nastavio put ka Ljubljani. Kao razlozi se pominju neslaganje sa idejama centralizovane vlade o statusu fakulteta $u$ Ljubljani i nastavak rada na Hradčanima, najstarijem i najvažnijem arhitektonskom dvorskom kompleksu u Pragu (Mušič 1971, 165). 


\section{A. Stamenković \\ Doprinos Jožeta Plečnika arhitekturi...}

Do dvadesetih godina prošlog veka o Plečniku se u Srbiji nije mnogo znalo. Beogradska kulturno-umetnička scena nije pokazivala interes za način rada blizak njegovom izrazu, shodno tome što se i u beogradskoj školi arhitekture negovao izraz drugačiji od prakse u Zagrebu ili Ljubljani (Mušič 1971, 165). Osim Strajnićeve monografije, ${ }^{9}$ Plečnikovoj popularnosti doprineo je Ivan Meštrović.

Godine 1913, 23. septembra, objavljen je Proglas Odbora za organizaciju umetničkih poslova, u kome se među članovima počasnog predsedništva pominje arhitekta Jože Plečnik. ${ }^{10} \mathrm{Na}$ tu funkciju imenovan je zaslugom Ivana Meštrovića, a bez prethodnog obaveštenja i pristanka (Mušič 1970, 250). Kulturno-prosvetna delatnost u Srbiji je u drugoj deceniji dvadesetog veka bila jasno obojena potrebom za nacionalnim ojačanjem i preporodom jugoslovenstva. ${ }^{11} \mathrm{~S}$ tim $\mathrm{u}$ vezi je Odbor za organizaciju umetničkih poslova ${ }^{12}$ zagovarao ideju o osnivanju Visoke škole likovnih umetnosti (Mušič 1970, 258). Da bi se zamisao realizovala, neophodno je bilo okupiti sposobne jugoslovenske umetnike, a naročito odrediti jednog arhitektu koji će rukovoditi svim umetničkim radionicama. Kosta Strajnić je u članku Za našu umetničku kulturu opisao program Visoke škole i predložio Plečnika za njenog direktora. Svoj izbor je pravdao činjenicom da Plečnik, osim što se aktivno bavi projektovanjem građevinskih objekata, ima značajno iskustvo u radu sa primenjenim umetnostima. Taj predlog je izneo i samom Plečniku, u pismu iz 27. oktobra 1913. godine, pokušavši da ga privoli da prihvati ponuđenu poziciju (Mušič 1970, 259). Dan kasnije je pismo sa istim predlogom, a sa pravdanjem mogućnošću delovanja na velikom, slobodnom ju-

\footnotetext{
${ }^{9}$ Strajnić, Kosta. 1920. Plečnik. Zagreb: Ćelap i Popović.

10 Pored Plečnika, mnoge značajne ličnosti kulturnog i umetničkog kruga toga vremena dovodile su se u vezu sa Odborom. Među njima su bili: Bogdan Popović, Andra Stevanović, Jovan Cvijić, Ivan Meštrović, Rihard Jakopič, Matija Jama, Ferdo Vesel, Nadežda Petrović, Kosta Strajnić i Marko Murat. Videti: Mušič, Marjan. 1970 „Plečnik u Beogradu“, ZLUMS 6: 249.

11 O jugoslovenstvu pogledati: Ignjatović, Aleksandar. 2007. Jugoslovenstvo u arhitekturi: 1904-1941. Beograd: Građevinska knjiga. O značaju koji je Plečnik imao u prvim godinama osnivanja Kraljevine SHS i o posmatranju Plečnikove umetnosti kroz prizmu jugoslovenstva pogledati: Strajnić, Kosta. 1925. „Za čast jugoslovenske kulture i umetnosti. Povodom našega učestvovanja na međunarodnoj izložbi u Parizu“, Srpski književni glasnik XV, br. 6: 461, ali i izvor iz dnevne štampe u kome se pominje kao „najveći jugoslovenski arhitekta“: Anonim. 12. 2. 1392. „Šezdesetogodišnjica najvećeg jugoslovenskog arhitekte“, Vreme, br. 3633: 2.

${ }^{12}$ Više informacija o ovom Odboru naći u: Medaković, Dejan. 1970. „Principi i program Odbora za organizaciju umetničkih poslova Srbije i Jugoslovenstva iz 1913. godine“, Zbornik Filozofskog fakulteta 11/1, 1970: 671-682.
} 
goslovenskom prostoru, arhitekti Plečniku uputio Ivan Meštrović (Mušič 1970, 259).

Ideja da dođe $u$ Beograd i učestvuje u profilisanju umetničke scene bila je primamljiva Plečniku, ali je isto tako izazivala nedoumice zbog mogućnosti da teška politička situacija utiče na njegov profesionalni položaj (Mušič 1970, 261; Jovanović 2016a, 59). Kako je po prirodi bio „usamljenički raspoložen i neborben čovek“, uputio je svom prijatelju Ivanu Meštroviću pismo u kome se zahvalio na predlogu i objasnio zašto ga ne može prihvatiti. Nekoliko meseci kasnije (17. aprila 1914. godine) piše pismo i Kosti Strajniću, te ljubazno odbija ponuđene funkcije rečima: „Pripadnost izvesnom narodu po Božjoj je volji. Ali takvo određenje obavezuje. Zbog toga me je ne malo puta zabolelo kad me je domovina potpuno ignorisala, domovina čija je sveta dužnost da svojoj deci pruži mogućnost vaspitavanja njihovih duševnih i telesnih snaga. " ${ }^{13}$ Iako je rešio da ne odustane od profesure na Akademiji u Pragu, značaj koji mu je predlogom za dolazak u Beograd dat uzburkao je nemačku političku i kulturnu javnost, što je nepovoljno uticalo na Plečnikovu senzitivnu ličnost.

\section{Dolazak u Beograd i crkva Sv. Antuna Padovanskog}

Prijateljstvo sa Meštrovićem i dobra poslovna saradnja sa slovenačkim franjevcima doneli su Plečniku projekat crkve Sv. Antuna Padovanskog u Beogradu. Ova crkva je uvrštena u red najznačajnijih sakralnih objekata Jožeta Plečnika (Damljanović 2005, 82; Ristić 2014, 198; Krečič 2005, 195-197; Jovanović 2016a, 61). Građena je dugo, od 1929, kada nastaje prvi projekat, do 1932. godine, kada se radovi na spoljašnjosti privode kraju, a osveštana je tek 8. decembra 1933. godine (Ristić 2014, 200). Opremanje crkve je postepeno izvođeno, i do danas nije u celosti završeno. Osim nekih neminovnih odstupanja usled promene liturgijske prakse, projekat se gradio $u$ skladu sa nacrtima koje je Plečnik za života razrađivao (Jovanović 2016a, 70-71).

Realizaciji objekta prethodili su dugi razgovori Plečnika i beogradskog župnika fra Anđelika Grgića, kao i dva projekta (Krečič 2005, 196). Prvi projekat je završen 1929. godine. Od njega se brzo odustalo, uglavnom zbog kupole velikih dimenzija, koja se nadovezivala na prilično široki valjkasti deo glavnog prostora crkve. Iako

${ }_{13}$ Oba pisma - ovo i pismo Meštroviću u celini - objavljena su u Mušičevom članku „Meštrović u Beogradu“ iz 1970. godine (ZLUMS 6: 261-263). 


\section{A. Stamenković \\ Doprinos Jožeta Plečnika arhitekturi...}

se ne može reći da je Plečnik imao neki konkretan uzor za ovakav projekat crkve, upotreba kupole kao završnog momenta eksterijera i prostorni koncept hrama dali su jasne asocijacije na rimski Panteon, ranohrišćanske rotonde (San Vitale u Raveni), ili na crkvenu arhitekturu Vizantije (Sv. Sergije i Vakh), i mogla bi se posmatrati kao pokušaj sinteze tradicije i modernih tokova u arhitekturi (Jovanović 2016a, 66). Razlog odbacivanja ovog motiva, međutim, nije do kraja razjašnjen. Pregledom dostupne građe može se zaključiti da se dovodio u vezu sa reminiscencijama na objekte muslimanskih (Hrausky, Koželj i Prelovšek 1998, 220) ili pravoslavnih bogomolja (Jovanović 2016a, 66), sa Plečnikovim „strahom” da je ta zamisao za domaće graditelje veoma zahtevan poduhvat (Prelovšek 1992, 251), ali i sa velikom svotom novca koja bi se u te svrhe morala izdvojiti (Manević 1983, 132).

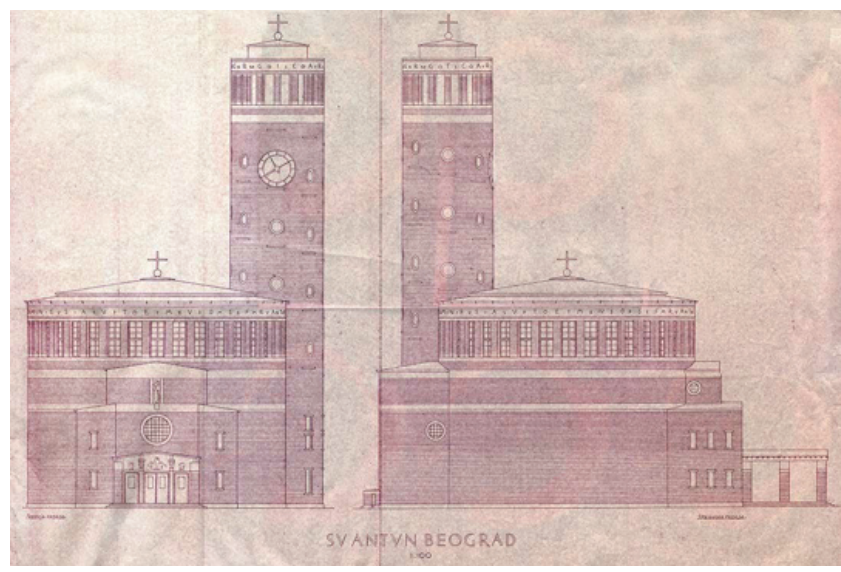

Sl. 1. Crkva Sv. Antuna Padovanskog plan fasada

Izvor: oris.hr

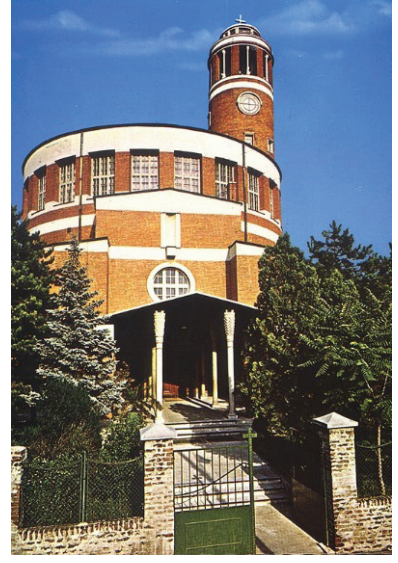

Sl. 2. Crkva Sv. Antuna fasada danas Izvor: Wikipedia.org

Crkva Sv. Antuna Padovanskog je prvi monumentalni rimokatolički hram podignut $\mathrm{u}$ širem gradskom jezgru Beograda (Deroko 1932, 630). U izgledu celine dominira kombinacija veoma razuđenih valjkastih oblika. To su prostor za okupljanje vernika, sa pratećim delovima, zvonik i svetilište (Alfirević 2015, 147; Krečič 2005, 195).

Centralni prostor, naos, ima tri jednake konhe. Jedna konha se nalazi u osovini broda i ima funkciju svetilišta (prezviterijuma), dok bočne obavljaju funkciju kapela. Sve tri su sa spoljne strane povezane niskim volumenom, zbog čega je i prostor između konhi dobio dva manja polukružna odeljenja, sa po dve niše sa prozorima. Jedno je namenjeno za ostavu, dok je drugo dobilo funkciju sakristije, i 
iz njega se direktno pristupalo polukružnoj ispovedaonici. Upravo $\mathrm{u}$ tom sakrivanju ispovedaonice $\mathrm{u}$ dubini konhe može se spoznati Plečnikovo dobro poznavanje kanona katoličke crkve (Sikošek 2017).

Da bi povezao zvonik sa prostorom crkve, Plečnik je upotrebio vezni element sa vretenastim stepenicama, koji na spratu vrši ulogu hora (Krečič 2005, 197).

Prema prvom projektu, neposredno iznad valjkastog centralnog dela crkve uzdizala bi se kupola velikih dimenzija, što je motiv viđen na Panteonu, vizantijskim hramovima, ali i na prvom Plečnikovom projektu za crkvu u Bogojini, u Prekomurju, iz 1924. godine (Krečič 2005, 197). Veoma brzo je Plečnik odbacio kupolu, zamenivši je ravnom tavanicom na koju je, da bi zadržao motiv kompozicije, postavio pseudosvetlosni tambur (Krečič 2005, 197). Primena ravne tavanice jače naglašava motiv prožimanja cilindričnih formi, te je u tom smislu realizovano rešenje koncepcijski jasnije od prvog projekta (Bernik i Golobič 1990, 44; Alfirević 2015, 148). U menjanju planova je i zvonik premešten s leve na desnu stranu oltarskog dela.

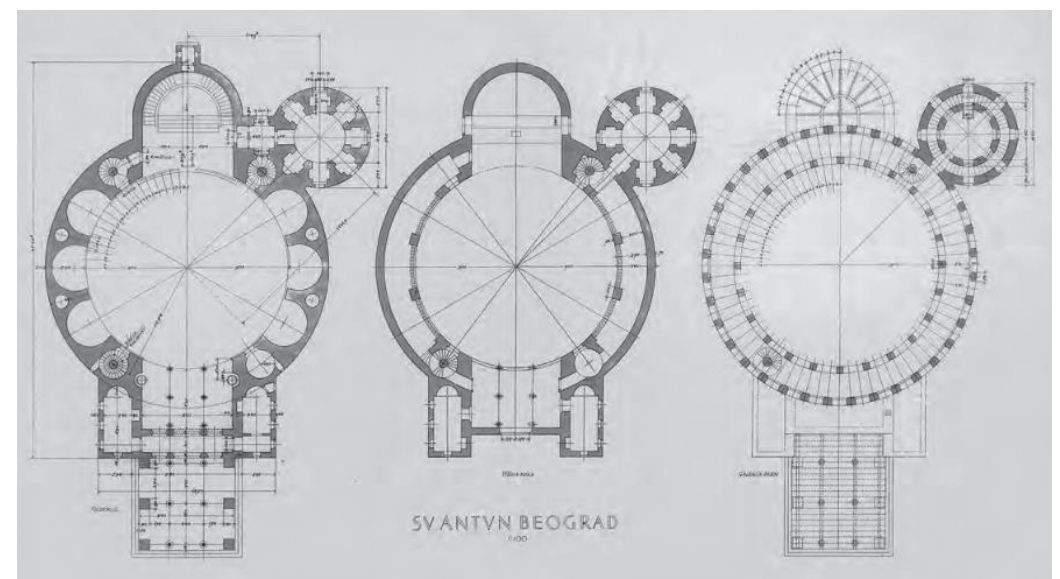

S1. 3. Osnove crkve Sv. Antuna Padovanskog u Beogradu Izvor: Nasleđe 6, str. 198

Iako neodgovarajuća za održavanje verskih službi, kružna forma crkve nije slučajno izabrana. Plečnik je Beograd smatrao orijentalnom sredinom, pa je s tim razmišljanjem i s pravoslavnom tradicijom povezana ideja o crkvi sa centralnom osnovom i zvonikom (Krečič1993, 108; Prelovšek 1999, 137-138), kao i zidanje opekom (Damljanović 2005, 82). 


\section{A. Stamenković \\ Doprinos Jožeta Plečnika arhitekturi...}

Spoljašnjost je naglašeno stroga zbog veoma pojednostavljenih formi, koje - po Plečnikovoj zamisli - najbolje izražavaju franjevački aksetizam (Alfirević 2015, 176). Utisku masivne monumentalnosti doprinela je upotreba jednog, primarnog geometrijskog oblika - valjka. Valjak je izdeljen betonskim frizovima na vence, koji odgovaraju podeli enterijera na zone. Prvi i drugi venac se protežu do visine prostora za okupljanje vernika. Na njih se neposredno nadovezuje sledeći, koji odgovara visini svetilišta. Četvrti venac okružuje crkvu ispod tavanice i obeležen je nizom jednakih, pravougaonih prozora, što bi se moglo smatrati pokušajem ublažavanja utiska masivnosti. Motiv pravougaonih prozora, jednako postavljenih i povezanih u niz može se videti i na drugim Plečnikovim crkvama, pre svega u Ljubljani i Pragu.

Oblikovanje zidova je strogo kontrolisano, pa je stremljenje u visinu, uobičajno za katoličke sakralne prostore, naglo prekinuto primenom ravne tavanice. Ekspresivna priroda arhitekte Plečnika došla je do izražaja kroz uređenje zgusnuto zaobljenih masa figurama anđela i isticanje prozorskih okvira plastikom (Kadijević 2012, 69).

Do glavnog portala dolazi se preko pokrivenog trema kvadratnog oblika, čiji krov na dve vode nose stubovi sa visokim, trubastim kapitelima na ulaznoj strani, odnosno pilastri na bočnim stranama. Svaki od stubova ukrašen je starohrišćanskim motivima. Forma kolonade stubova sa trubastim kapitelima ponavlja se u predvorju crkve (Krečič 2005,198$)$.

Ulazni deo se, takođe, završava dvoslivnim krovom, a svetlost je do njega dopirala preko velikog okulusa na fasadi. Ulaz u crkvu je dodatno naglašen postavljanjem nižih, jednobrodnih kapela sa apsidama uz bočne zidove. Njihovi volumeni su blago pomaknuti od ulaznog dela i osvetljeni sa dva niza prozora na fasadi i sa strane. ${ }^{14}$ U želji da stvara arhitekturu koja prenosi poruku, Plečnik je veliku važnost davao fasadi..$^{15}$ Koncentracija dekorativnih elemenata na ulaznom delu građevine reflektovala je Plečnikovu sklonost ka dekorativizmu i način na koji je tretirao dekorativne elemente (Prosen 2014, 502).

14 O nameni, opremi bočnih kapela, enterijeru i mogućnostima njihove zaštite pogledati: Krečič, Peter. 2005. „Crkva Sv. Antuna Padovanskog u Beogradu - ocena zaštite spomenika i smernice obnove“, Nasleđe 6: 195-210.

${ }^{15}$ Na značaj koji Plečnik daje fasadi i upotrebi dekoracije ukazuje Peter Krečič u članku „Jože Plečnik and Art Deco“, citirajući Plečnika: „Fasada bez dekoracije je kao čovek bez osmeha“" (prevod autora). 


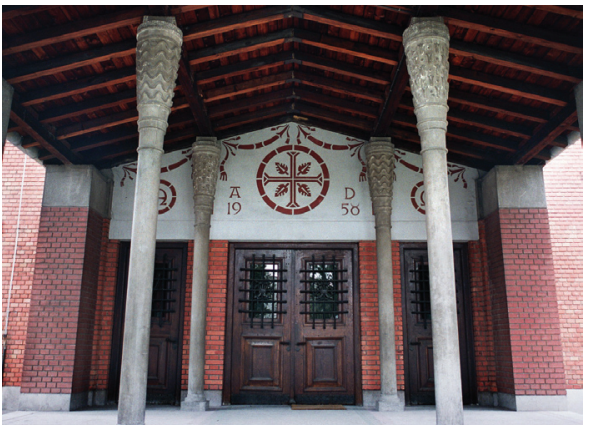

Sl. 4. Ulazni trem Izvor: Wikipedia.org

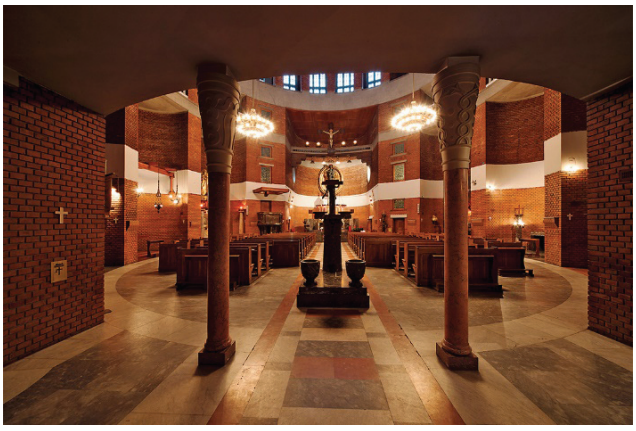

Sl. 5. Enterijer crkve Sv. Antuna Padovanskog Izvor: oris.hr

Zidanje opekom je motiv koji povezuje spoljašnji i unutrašnji deo crkve. Upotreba horizontalnih venaca od betona uticala je na podelu prostora na zone u enterijeru. Prvu i drugu zonu određuje kružni omotač centralnog broda sa konhalnim udubljenjima na sredini zida i svetilištem. One nisu jasno podeljene nekim izdvojenim elementima, osim iznad ulaza, gde je predviđen prostor za hor. Treća zona se pruža iznad ravne tavanice konhi i svetilišta, obuhvatajući poprečnu gredu na stepenastim konzolama, na koju je postavljen krst sa raspetim Hristom (Prelovšek 1999, 145) i galerije sa balustradama iznad hora i konhi (Jovanović 2016a, 69). Četvrta zona se pruža iznad galerija i obuhvata kružni hodnik (deambulatorijum), koji je sa unutrašnje strane pokriven zidanim pilastrima od opeke bez kapitela, a sa spoljne - pravougaonim prozorima. Na poslednju zonu se nadovezuje arhitrav, poput petog venca koji povezuje gornje pilastre sa ravnom drvenom tavanicom (Krečič 2005, 198).

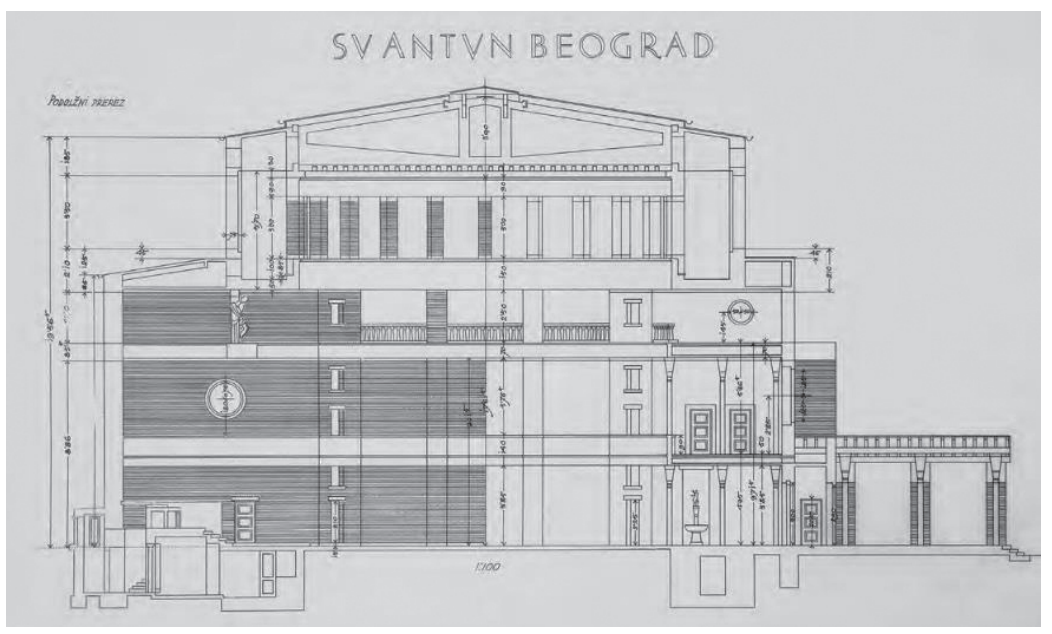

Sl. 6. Poprečni presek crkve Sv. Antuna Padovanskog u Beogradu Izvor: Nasleđe 6, str. 199 


\section{A. Stamenković \\ Doprinos Jožeta Plečnika arhitekturi...}

Plečnik je sam uradio projekte i za enterijer crkve. Suprotno od uprošćenog izgleda spoljašnjeg omotača, visina od $25 \mathrm{~m}$ nudila je mogućnost raščlanjenije organizacije sadržaja $-u$ formi galerija, stepenica, propovedaonica ili pevnica, te u enterijeru dominira raskošna materijalizacija raznovrsnih oblika (Tucić, 2011, 4). Raščlanjenost unutrašnjeg prostora rezultat je Plečnikove ideje da se sistem konhi sakrije u omotaču broda, čime je postignut efekat kontrafora koji objektu obezbeđuju čvrstinu i stabilnost (Alfirević 2015, 148-149). Arhitekta je ovaj koncept koristio i ranije, ali ga je na beogradskoj crkvi značajno unapredio (Krečič 2005,197 ).

Oprema za crkvu projektovana je neposredno po završetku izgradnje i izvođena je $u$ dve faze. Veći deo je završen pre početka Drugog svetskog rata, a jedan manji deo kasnije, i on ne odgovara $u$ potpunosti prvobitnim Plečnikovim skicama (Krečič 2005, 200, Jovanović 2016a, 71). Razmišljajući o enterijeru u kome svi treba da se osećaju dobro, Plečnik je razmišljao i o opremi koja je simbolična i prepoznatljiva i sa kojom se vernici identifikuju. Kao duboko religiozan čovek, crkvu je posmatrao kao mesto okupljanja zajednice. Želeo je da kroz sakralnu umetnost dostigne katoličke ideale (Sikošek 2017), pa je vodio računa o ideji trostepene podele prostora za sve kategorije učesnika u obredu. Sveštenstvu, koje vodi obred, namenjen je prostor svetilišta s velikim oltarom i prostori u konhama $\mathrm{s}$ bočnim oltarima. Centralni brod je određen za učesnike u obredu, dok su za posmatrače i posetioce predviđene galerije iznad konhi i deambulatorijum (Krečič 2005, 200).

Strogi oblici crkvenog mobilijara izvedeni su u mermeru i stilizovani starohrišćanskim, romanskim i baroknim motivima (Krečič 2005 , 198). Oltari sa pratećim opremama izvedeni su, uglavnom, prema prvobitnim Plečnikovim projektima. Crkvenu opremu je izvodio slovenački vajar Božo Pengov, osim skulpture Sv. Antuna koja dominira na zidu iznad glavnog oltara, a koju je izradio Ivan Meštrović (Krečič 2005, 200; Ristić 2014, 201; Jovanović 2016a, 60).

Kružnu osnovu je Plečnik ponovio na zvoniku. Poput glavnog dela crkve, zvonik se završava ravnom tavanicom, odnosno terasom sa skulptoralnom kompozicijom krsta na sredini (Krečič 2005, 197; Jovanović 2016a, 71). Ovaj se zvonik smatrao rizičnim poduhvatom, pa je izgrađen tek 1962. godine, u drugoj fazi radova na crkvi, posle smrti arhitekte, a zahvaljujući njegovom učeniku i asistentu Janezu Valentinčiču. Visok je $52 \mathrm{~m}$ i blago je nagnut (oko $50 \mathrm{~cm}$ ). Pored brojnih pravougaonih prozorskih okvira, dinamiku u kompoziciju zvonika unosi sužavanje oblika pri vrhu. Završni sprat, umesto punih 
zidova, odlikuju stubovi od opeke i kamena, na kojima je postavljen venac i, iznad njega, lanterna (Jovanović 2016a, 71). I spoljašnji izgled i unutrašnji prostor koncepcijski odgovaraju maniru u kojem je Plečnik izveo centralni deo crkve (Ristić 2014, 200).

Plečnik je projektom za crkvu Sv. Antuna želeo da simbolizuje monaški red i time istakne celokupnu različitost katoličanstva (Damljanović 2005, 81; Tucić 2011, 6). Ova crkva svojim geometrijskim formama deluje monumentalno i veoma moderno. Ona upućuje na razmišljanje o ideološkoj ulozi hrišćanskog hrama i funkciji koju svaki element građevine $u$ tom kontekstu dobija. U koncepciji dominira skulptoralno prožimanje valjkastih oblika, što je, pored plastičnosti površina, primarna odlika ekspresionističkih tendencija između svetskih ratova u Srbiji (Alfirević 2015, 149; Kadijević 2012, 62). Ipak, ovde nema bogatstva ekspresionističkih elemenata i kompozicije, što možemo videti na nekim drugim Plečnikovim objektima, a zbog potrebe vraćanja klasičnom stilu, koji je autor izabranim oblicima želeo da dosegne (Strajnić 1920; Bernik i Golobič 1990, 42-53). Ovo Plečnikovo delo je svojim umetničkim formama uticalo na graditelje srpske sakralne arhitekture (Prosen 2014, 502).

Crkva ima status spomenika kulture od 1994. godine (NKD SK 2051).

\section{Projekat rimokatoličke crkve u Obrenovcu}

Malo je poznato da je arhitekta Plečnik 1934. godine uradio projekat za rimokatoličku crkvu Presvetog Srca Isusovog u Obrenovcu, na molbu Andreja Tumpeja, župnika beogradske župe Sv. Ćirila i Metodija (Jovanović 2016c, 75), a do danas je ostalo nerazjašnjeno zašto ova crkva nije izgrađena. Ovo je jedan od retkih projekata koje je Plečnik uradio bez prethodnog upoznavanja sa ambijentom, što i sam pominje u pismima župniku, koja se čuvaju u Arhivu pomenute župe (Jovanović 2016c, 77).

Na osnovu sačuvanog projekta prepoznaje se crkva nevelikih dimenzija, sa apsidom, sakristijom i prostorijom za sveštenike. Zvonik je i u ovom slučaju zaseban deo celine i domira visinom u odnosu na gabarit crkve. Po morfološkim karakteristikama i stilizaciji tradicionalnih oblika na moderan način, podseća na Plečnikov manir iz tridesetih godina prošlog veka. 


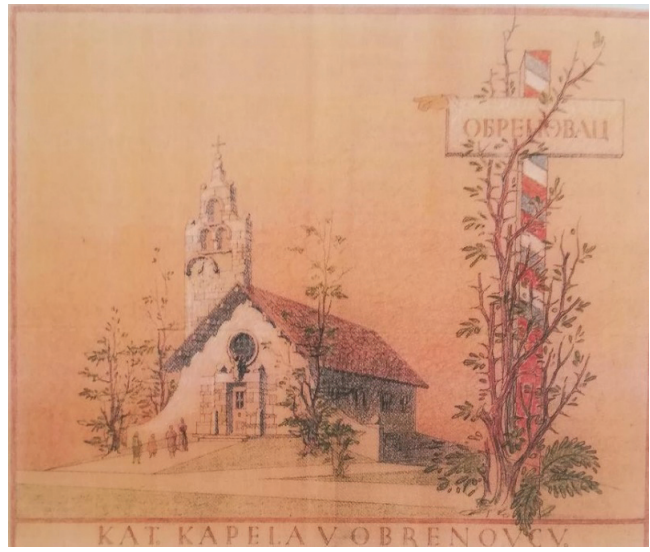

S1. 7. Projekat za rimokatoličku crkvu u Obrenovcu Izvor: Zoran M. Jovanović Slovenski umetnici u Beogradu, str. 76
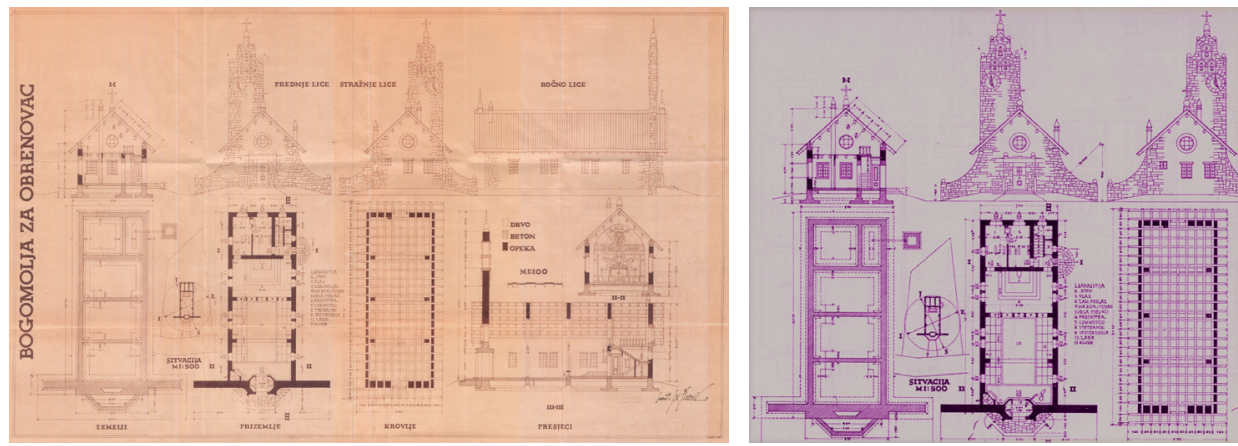

Sl. 8. Projekti za rimokatoličku crkvu u Obrenovcu Izvor: Katalog izložbe Jože Plečnik, str. 3

\section{Konkurs za zgradu Državnog sekretarijata za poslove narodne odbrane - DSNO (danas Generalštab)}

Jedno od značajnijih zabeleženih pojavljivanja Plečnikovog imena na konkursima za javne objekte $u$ Beogradu bilo je na konkursu ${ }^{16}$ za zgradu Državnog sekretarijata za poslove narodne odbrane (dalje DSNO), raspisanom 1953. godine (Sponza 1998, 303-310; Matejić 2012 , 167). Kako je i ranije vodio računa o mestu koje će objekat zauzimati nakon izgradnje, Plečnik je istupio sa rešenjem objekta

\footnotetext{
${ }^{16}$ Godine 1953. raspisan je drugi konkurs. Prvi je održan šest godina ranije. Više detalja o konkursu videti u: Kovačević, Bojan. 2001. Arhitektura zgrade Generalštaba: monografska studija dela Nikole Dobrovića, Beograd: Novinsko-informativni centar,Vojska“.
} 
i predlogom za urbanističko uređenje prostora na kome će graditi. Vodeći računa o nameni objekta, te potrebnoj funkcionalnosti, on u konkursnom rešenju predlaže dve zgrade, povezane u jedinstvenu celinu, do kojih se dolazi preko reprezentativnog trga, čime odstupa od uobičajenih uličnih proširenja (Sponza 1998, 305).

Primenom izrazito vertikalnih formi, Plečnik je objektu obezbedio neophodnu reprezentativnost. Nije bežao od asimetrije i dekorativnosti, već je smatrao da one daju objektima izražajnost, i zbog toga su ova dva motiva uvek prisutna na njegovim projektima. Prvom objektu iz celine DSNO izražajnost bi dale dve kule bogato dekorisane plastikom, a postavljene s obe strane Nemanjine ulice. Na drugom objektu je, da bi naglasio asimetriju, predvideo samo jednu kulu na sredini fasade koja gleda na Nemanjinu ulicu (Matejić 2012, 170).

Iako je Plečnik bio obeležen kao „učesnik van konkurencije“, prvo mesto i izvođenje je na konkursu za zgradu DSNO-a dobio projekat Nikole Dobrovića.
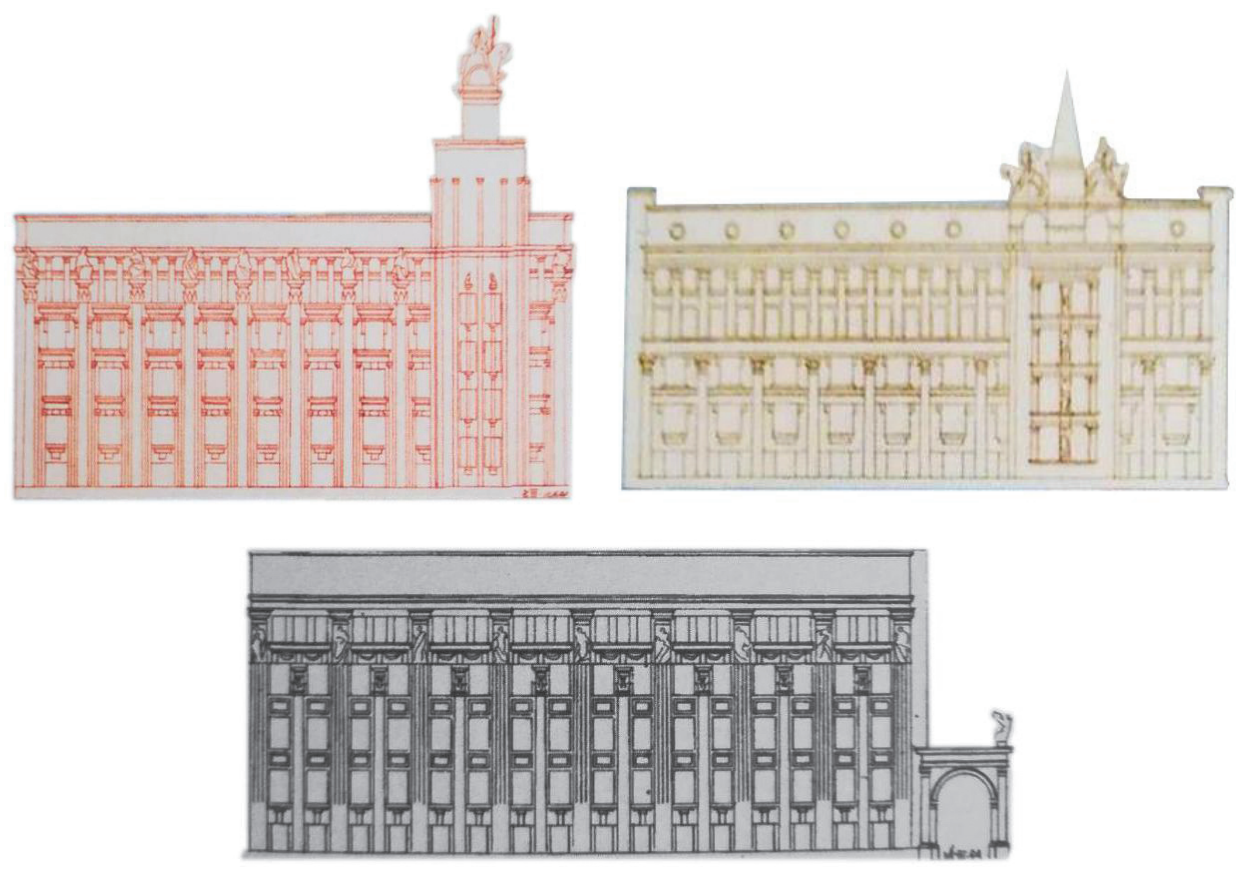

S1. 9. Neizvedeni projekat zgrade DSNO

Izvor: Katalog izložbe Jože Plečnik, str. 3 


\section{A. Stamenković \\ Doprinos Jožeta Plečnika arhitekturi...}

\section{Enterijer kapele Usmiljenki, sa oltarom u zgradi Karitasa beogradske Nadbiskupije}

Godine 1956. Plečnik je osmislio projekat enterijera kapele sa drvenim oltarom za sestre Kćeri hrišćanske ljubavi Sv. Vinka Paulskog, odnosno - za usmiljenke (Jovanović 2016b, 79; Kocjan 2017, 1). Kapela se nalazi u zgradi Karitasa beogradske Nadbiskupije, $u$ Višegradskoj ulici u Beogradu. Prvobitno je pripadala lekaru Ljubomiru Zdravkoviću, ali su je usmiljenke otkupile 1954. godine i preuredile za svoje potrebe (Jovanović 2016b, 79).

Pored Plečnika, angažovani su majstor Franc Koncilija iz Kamnika za stolarske radove i Alojzij Pirnat iz Ljubljane za izradu tabernakla i krsta nad oltarom (Jovanović 2016b, 80).

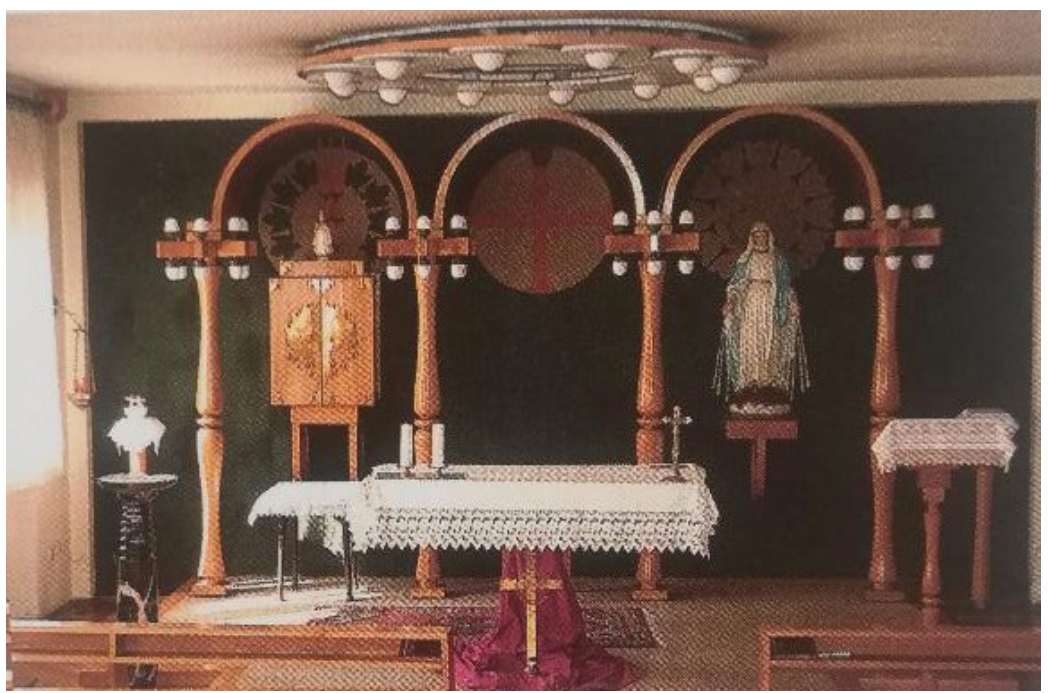

Sl. 10. Oltar u kapeli Usmiljenki

Izvor: Zoran M. Jovanović Slovenski umetnici u Beogradu, str. 80

Pored navedenih dela, Plečnik je 1950. godine potpisao i nacrt oltarske menze za beogradsku rimokatoličku crkvu Sv. Petra Apostola, u Makedonskoj ulici, ali je ona postavljena tek 1960. godine, posle smrti arhitekte (Jovanović 2016a, 60), kao i idejno rešenje ispovedaonice za župnu crkvu Krista Kralja. ${ }^{17}$

Povodom obeležavanja 145 godina od rođenja i 60 godina od smrti ovog uglednog arhitekte, $\mathrm{u}$ decembru 2017. godine su u Ustanovi kulture „Parobrod“ i u crkvi Sv. Antuna u Beogradu održane svečana akademija i izložba pod nazivom: „Jože Plečnik, arhitekta,

\footnotetext{
${ }^{17}$ Pogledati u Arhivu Nadbiskupije beogradske (kat. jedinica br. 267/1929).
} 
Ljubljana - Prag - Beograd“. Govorilo se o Plečnikovim arhitektonskim ostvarenjima u ovim gradovima i istaknuta je njegova veza sa Beogradom kroz prikaz realizovanih i neizvedenih objekata.

\section{Zaključak}

Jože Plečnik, arhitekta, urbanista i profesor, bio je jedan od važnih kreatora arhitektonske kulture u prvoj polovini prošlog veka. Svojom umetnošću i projektantsko-pedagoškom aktivnošću otvorio je put za prihvatanje novih estetskih praksi na čitavom prostoru bivše jugoslovenske zajednice. Specifičan arhitektonski jezik, sa klasičnim, renesansnim i baroknim referencama, i način na koji je tretirao kontekst uobičajenih aktivnosti u gradu rezultirali su stvaranjem posebnih ideoloških toposa, koji su generatori određenog prostora i koji doprinose razmatranju istorijske pozadine, $u$ istoj meri koliko i razmatranju psiholoških aspekata odnosa čoveka prema sopstvenoj tradiciji.

Kao svestrani umetnik, stvarao je mnogo toga, ali se najviše posvećivao sakralnom stvaralaštvu. Stoga je neophodno sagledavati Plečnikov rad u celini i sa različitih strana, kako bi se upotpunila analiza načina na koji je stvarao svoju umetnost.

Ovaj rad je rezultat pokušaja osvetljavanja Plečnikove veze sa Beogradom, uz kratku analizu arhitekture jedinog izvedenog objekta - crkve Sv. Antuna Padovanskog i pomen drugih manje poznatih angažovanja. Primećeno je da, bez obzira na to da li su u pitanju crkveni ili profani objekat, njegove radove karakteriše manir da građevine, osim što učestvuju u komunikaciji sa okolinom, nose izvesnu simboličnu poruku. Otuda brojne kombinacije simboličnih elemenata. Shodno činjenici da Plečnikov rad izaziva različito likovno i ikonografsko čitanje arhitekture, cilj ovog priloga je da se doprinese savremenim i budućim istraživanjima pomenutih objekata, ali i Plečnikove biografije u celini.

\section{Literatura}

Alfirević, Đorđe. 2015.Ekpresionizam u arhitekturi XX veka u Srbiji. Doktorska disertacija. Beograd: Arhitektonski fakultet.

Arhiv Nadbiskupije beogradske.

Bernik, Stane i Marjan Golobič. 1990. Slovene Architecture from Secession to Expressionism and Functionalism. The Journal of Decorative and Propaganda Arts, vol. 17: 42-53. 


\section{A. Stamenković \\ Doprinos Jožeta Plečnika arhitekturi...}

Damljanović, Tanja. 2005. Dva hrama za dve konfesije : traganje za modernovizantijskim. Nasleđe 6: 77-83.

Deroko, Aleksandar. 1932. Prvi monumentalni hram u Beogradu. Srpski književni glasnik 36: 630-631.

Dinulović, Radoje i Romana Bošković. 2010. Proširena scenografija: scenski dizajn od konvencionalnog pozorišta do savremenih umetničkih praksi. Zbornik Fakulteta dramskih umetnosti 17: str. 47-55.

Glišić, Katarina. 2007. Rimokatoličke crkve na teritoriji Beograda. Magistarski rad. Beograd : Filozofski fakultet.

Hrausky, Andrej, Koželj Janez i Damjan Prelovšek. 1998. Plečnik v tujini : vodnik po arhitekturi. Ljubljana : Dessa.

Jovanović, Zoran M. 2016a. Nasleđe Jože Plečnika i njegovih sunarodnika na beogradskoj Zvezdari - u središtu župe Sv. Antuna. Slovenački umetnici u Beogradu. Ljubljana : Družina.

Jovanović, Zoran M. 2016b. Kapela usmiljenki, o Plečniku i drugima „od slovenačkog roda“. Slovenački umetnici u Beogradu. Ljubljana : Družina.

Jovanović, Zoran M. 2016c. Obrenovac, gradić u vidokrugu Beograda - mesto koje je trebalo da zrači vizijom Jože Plečnika. Slovenački umetnici u Beogradu. Ljubljana : Družina.

Jože Plečnik, arhitekta : Ljubljana, Prag, Beograd : katalog izložbe. (2017). Beograd : Nacionalni savet slovenačke nacionalne manjine : Nacionalni savet češke nacionalne manjine : Društvo Sava.

Kadijević, Aleksandar. 2012. Ekspresionizam u beogradskoj arhitekturi (1918-1941). Nasleđe 13: 59-77.

Krečič, Peter. 1990. Jože Plečnik and Art Deco. The Journal of Decorative and Propaganda Arts, vol. 17: 26-35.

Krečič, Peter. 1992. Jože Plečnik. Ljubljana : DZS.

Krečić, Peter. 1993. Plečnik : The Complete Works. London : AD.

Krečič, Peter. 1999. Jože Plečnik. Moderni klasik. Ljubljana : DZS.

Krečič, Peter. 2005. Crkva Sv. Antuna Padovanskog u Beogradu - osena zaštite spomenika i smernice obnove. Nasleđe 6: 195-210.

Kovačević, Bojan. 2001. Arhitektura zgrade Generalštaba: monografska studija dela Nikole Dobrovića, Beograd : Novinsko-informativni centar,Vojska“.

Lovrenović, Ivan. 2012. Jozo Džambo, Architectura perennis. Dostupno na: http://ivanlovrenovic.com/2012/07/jozo-dzambo-architecturaperennis/ (pristupljeno novembra 2018).

Manević, Zoran. 1983. Plečnik u Beogradu. Sveske Društva istoričara umetnosti 14-15: 132134.

Manojlović Pintar, Olga. 2008. „Uprostoravanje ideologije: Spomenici Drugog svetskog rata i kreiranje kolektivnih identiteta“. U Dijalog povjesničara/istoričara 10/1, pr. I. Graovac, 287-307. Zagreb : Friedrich Neumann Stiftung. 
Matejić, Marko. 2012. Prilog proučavanju zgrade Generalštaba Nikole Dobrovića: koncept i iskustvo prostora. Nasleđe 13: 167-183.

Medaković, Dejan. 1970. Principi i program Odbora za organizaciju umetničkih poslova Srbije i Jugoslovenstva iz 1913. Godine. Zbornik Filozofskog fakulteta 11/1: 671-682.

Mušič, Marjan. 1970. Plečnik u Beogradu. Zbornik za likovne umetnosti Matice Srpske 6: 249265.

Mušič, Marjan. 1971. Plečnik in Beograd. Zbornik za likovne umetnosti Matice Srpske 7: 165-176.

Mušič, Marjan. 1973. Plečnik in Beograd. Zbornik za likovne umetnosti Matice Srpske 9: 327-335.

Petrić, Jelena and Martin Graham. 2008. „Heritage and Urban Regeneration: Lessons from Plecnik“. U Chronocity: The Scale of Sustainable Change: Heritage Value and Future Opportunities and Challenges, ed. Dimitra Babalis, 105-117. Firenze : Alinea Editrice.

Prelovšek, Damjan. 1992. Josef Plečnik 1872-1957 : Architectura Perennis. Salzburg ; Wien : Residenz Verlag.

Prelovšek, Damjan. 1999. Plečnikova sakralna umetnost. Koper : Ognjišče.

Prelovšek, Damjan. 2000. Arhitekt Plečnik in sakralna umetnost. Poligrafi (tematska številka „Religija in umetnost podobe“) 19/20: 135-145.

Prosen, Milan. 2014. Ar deko u srpskoj arhitekturi. Doktorska disertacija. Univerzitet u Beogradu - Filozofski fakultet.

Quek, Raymond, Darren Deane and Sarah Butler (eds). 2012. Nationalism and Architecture. Farnham : Ashgate: 101-105.

Ristić, Snežana. 2014. Skriveno blago Beograda. Oris 88: 196.

Sikošek, Majda. 2017. Jože Plečnik - jedinstveni. Dostupno na: http:// lepotazivota.rs/joze-plecnik-jedinstveni/ (pristupljeno novembra 2018).

Sponza, Ante.1998. „Zapisnik o radu žirija užeg konkursa za idejne skice zgrade DSNO“. U Nikola Dobrović: eseji, projekti, kritike, izbor i uvodni tekstovi Miloš R Perović i Spasoje Krunić, 303-310. Beograd : Arhitektonski fakultet Univerziteta u Beogradu : Muzej nauke i tehnike, Muzej arhitekture.

Strajnić, Kosta. 1920. Plečnik. Zagreb : Ćelap i Popović.

Strajnić, Kosta. 1927. Josip Plečnik 1872-1957. Letopis Matice srpske 312, sv. 2/3: 404-407.

Tucić, Hajna. 2011. Crkva svetog Antuna Padovanskog. Beograd : Zavod za zaštitu spomenika kulture grada Beograda.

Vasović-Mekina, Svetlana. 2007. Gospodin, a ne drug. Dоступно на: http://www.politika.rs/scc/clanak/20503 (приступљено 8. 5. 2018).

Vreme. 1932. Šezdesetogodišnjica najvećeg jugoslovenskog arhitekte. Vreme, бр. 3633 (12. februar): 2. 


\section{A. Stamenković \\ Doprinos Jožeta Plečnika arhitekturi...}

Aleksandra Stamenković

Založniška hiša Klett

Beograd, Srbija

a_stamenkovic@ymail.com

\section{PRISPEVEK JOŽETA PLEČNIKA K ARHITEKTURI BEOGRADA}

Jože Plečnik pripada generaciji pomembnih slovenskih in jugoslovanskih arhitektov, katerih dela so pustila izrazit pečat na Dunaju, v Pragi, Ljubljani, pa tudi v Beogradu. Svojo umetniško pot je gradil na temeljih klasične arhitekture, v času deklariranja modernega gibanja $\mathrm{v}$ umetnosti. Iz spoja zgodovinskih in sodobnejših umetniških tokov je nastal specifičen umetniški izraz Jožeta Plečnika. Odklon od aktualnih tokov in čistih, a praznih površin predstavlja poskus posodabljanja graditeljske dediščine s primesmi edinstvenega umetniškega duha. Njegova dekorativna arhitektura je precej bogatejša in kompleksnejša od tistega, kar sporoča na prvi pogled, in komunicira tako z neposrednimi koristniki kot $\mathrm{s}$ tistimi, ki se z njo ukvarjajo prek znanstvenoraziskovalnih postopkov. Cilj pričujočega prispevka o Plečnikovem delu je poskus osvetlitve njegovega doprinosa $\mathrm{k}$ javnemu prostoru Beograda, ki ga reprezentativno odraža cerkev sv. Antona Padovanskega v Bregalnički ulici (občina Vračar).

Ključne besede: Jože Plečnik, Beograd, cerkev sv. Antona, rimskokatoliška cerkev v Obrenovcu, sakralna arhitektura, kapela Usmiljenki, DSNO

\section{Aleksandra Stamenković \\ Klett Publishing House \\ Belgrade, Serbia \\ a_stamenkovic@ymail.com}

\section{JOŽE PLEČNIK'S CONTRIBUTION TO BELGRADE ARCHITECTURE}

Jože Plečnik belongs to the generation of the prominent Slovenian and Yugoslav architects whose artistic style left a significant imprint on the architecture of Vienna, Prague, Ljubljana and Belgrade. At the time when modern art movements were rising, Plečnik was developing his style relying on classic architectural sources. Jože Plečnik's specific artistic expression was a result of the fusion between historical and contemporary art movements. His departure from the contemporary tendencies and plain and empty surfaces was an attempt to modernize architectural heritage using the elements of a distinct artistic spirit. His decorative architecture is considerably more diversified and complex than the first-glance 
impression indicates. It communicates both with the users and with researchers. This study seeks to highlight Plečnik's contribution to the transformation of Belgrade's public space, embodied in the representative church of St. Anthony of Padua in Bregalnička Street in the Vračar Municipality.

Keywords: Jože Plečnik, Belgrade, St. Anthony’s church, Roman Catholic church in Obrenovac, sacral architecture, Chapel of the Daughters of Charity, DSNO 